\title{
Juoksutusmahaan infusoidun rasvalisän vaikutus ummessaolevien lehmien insuliiniresistenssin kehittymiseen
}

\author{
Siru Salin ${ }^{1)}$, Tuomo Kokkonen ${ }^{1)}$, Milla Kuitunen ${ }^{1)}$, Juhani Taponen ${ }^{2)}$, Kari Elo $^{1)}$ ja Aila Vanhatalo ${ }^{1)}$ \\ ${ }^{1)}$ Kotieläintieteen laitos, PL 28, 00014 Helsingin yliopisto \\ ${ }^{2)}$ Kliinisen tuotantoeläinlääketieteen laitos, Helsingin yliopisto, Leissantie 43 B, 04920 Saarentaus \\ etunimi.sukunimi@helsinki.fi
}

\section{Tiivistelmä}

Poikimisen läheisyydessä insuliinista riippuvaisiin ääreiskudoksiin kehittyvän insuliiniresistenssin avulla lypsylehmä ohjaa ravintoaineita sikiön ja utareen käyttöön. Insuliiniresistenssi lisää rasvakudoksen lipolyysiä ja veren vapaiden rasvahappojen (NEFA) pitoisuutta. Suurentunut veren NEFApitoisuus vähentää syöntiä ja lisää aineenvaihduntasairauksien riskiä poikimisen läheisyydessä. Kokeellisesti on osoitettu, että runsaasti tyydyttyneitä rasvahappoja sisältävän rasvaemulsion infuusio verenkiertoon lisäsi ei-tiineiden, ummessaolevien lehmien insuliiniresistenssiä glukoosirasituskokeen perusteella. Pääosin tyydyttymättömiä rasvahappoja sisältävän pellavasiemenöljyn infuusio puolestaan paransi näiden lehmien kudosten insuliiniherkkyyttä.

Tutkimuksessa selvitettiin juoksutusmahaan infusoidun rasvalisän vaikutusta tiineiden, ummessaolevien lypsylehmien insuliiniresistenssin kehittymiseen. Koe-eläiminä oli 6 toista kertaa poikivaa, pötsifistelöityä ay-lehmää. Koe tehtiin 3 x 3 latinalaisen neliön koekaavion mukaan. Koejaksot kestivät 5 vrk, ja jaksojen välissä oli samanpituinen tauko. Koejaksojen aikana lehmät saivat seosrehua $95 \%$ laskennallisesta energian tarpeesta rasvainfuusioiden sisältämä energiamäärä huomioiden. Koekäsittelyt olivat vesi (V), tali (T) ja camelinaöljy (C). Infusoitu määrä oli $500 \mathrm{ml} / \mathrm{pv}$, joka annettiin 10 kerta-annoksena (50 ml/krt) juoksutusmahaan $2 \mathrm{~h}$ välein klo 6-24. Jakson 5. päivänä klo 9 tehtiin glukoosirasituskoe ja klo 19 insuliinivastekoe. Verinäytteitä otettiin glukoosin annon jälkeen $3 \mathrm{~h}$ ajan (12 krt) ja insuliinin annon jälkeen $2 \mathrm{~h}$ ajan (10 krt). Lehmät olivat paastolla $1 \mathrm{~h}$ ennen kokeita sekä näiden aikana. Verinäytteistä määritettiin plasman NEFA-, glukoosi- ja insuliinipitoisuudet. Pitoisuuksiin sovitettiin eksponentiaalinen käyrä, jonka avulla laskettiin poistumisnopeus (CR) ja puoliintumisaika $\left(\mathrm{T}_{1 / 2}\right)$. Lisäksi laskettiin pitoisuus-aikakäyrän alainen pinta-ala (AUC).

Rasvainfuusio lisäsi odotetusti plasman NEFA-pitoisuutta $(\mathrm{P}<0,01)$. Rasvainfuusio hidasti glukoosirasituskokeen perusteella endogeenisen insuliinin stimuloimaa glukoosin soluunottoa. Rasvan anto hidasti glukoosin poistumista ja pidensi sen puoliintumisaikaa kontrolliryhmään verrattuna $(\mathrm{P}<0,05)$. Myös insuliinivastekokeessa rasvainfuusio heikensi insuliinin vaikutusta glukoosin poistumiseen. Glukoosin minimipitoisuus ja puoliintumisaika olivat rasvakäsittelyillä suuremmat kuin kontrolliryhmällä $(\mathrm{P}<0,05)$ ja glukoosin poistumisnopeus pienempi kuin kontrolliryhmällä $(\mathrm{P}=0,01)$, samoin AUC:n itseisarvo $(\mathrm{P}<0,01)$. Tali- ja camelinaöljykäsittelyjen välillä ei ollut eroja glukoosin poistumisessa.

Koetulosten perusteella voidaan todeta, että rasvainfuusioiden avulla aiheutettu hyperlipidemia heikensi lypsylehmien insuliiniherkkyyttä ja -vastetta poikimisen läheisyydessä glukoosirasitus- ja insuliinivastekokeiden aikana. Tulokset eivät tue teoriaa, jonka mukaan runsaasti tyydyttymättömiä rasvahappoja sisältävä rasvalisä parantaa insuliiniherkkyyttä.

Asiasanat: lypsylehmä, insuliiniresistenssi, glukoosirasitus, hyperlipidemia 


\section{Johdanto}

Sopeutuminen maidontuotannon alkamiseen on lypsylehmälle suurin aineenvaihdunnallinen muutos, jonka se joutuu kohtaamaan tuotoskauden aikana. Poikimisen läheisyydessä energiaaineenvaihdunnassa tapahtuvat muutokset ohjaavat ravintoaineita maidontuotannon kannalta tärkeisiin kudoksiin. Insuliinista riippuvaisiin ääreiskudoksiin kehittyvä insuliiniresistenssi on yksi tärkeimmistä sopeutumismekanismeista, jonka avulla lehmä säästää glukoosia maitorauhasen käyttöön (Bell 1995). Insuliiniresistenssillä tarkoitetaan heikentynyttä insuliinin vaikutusta ääreiskudoksissa. Insuliiniresistenssin johdosta glukoosin käyttö kudoksissa vähenee ja plasman insuliinipitoisuus on pysyvästi koholla. Lisääntyneestä insuliinipitoisuudesta huolimatta insuliinin aiheuttama biologinen vaste elimistössä on heikentynyt (Haffner ym. 1995).

Insuliiniresistenssin kehittymiseen liittyy suurentunut veren vapaiden rasvahappojen (NEFA) pitoisuus, mikä lisää rasvan kertymistä lihaksiin ja maksaan. Rasvan kertyminen kudoksiin ja lisääntynyt veren vapaiden rasvahappojen määrä estävät insuliinin stimuloimaa glukoosin soluunottoa (Lewis ym. 2002). Useat tutkimukset osoittavat, että poikimisen läheisyydessä ääreiskudoksiin kehittyvä insuliiniresistenssi on merkittävä aineenvaihdunta- ja lisääntymistoimintojen häiriöihin liittyvä riskitekijä (Oikawa \& Oetzel 2006, Pires ym. 2007, Bossaert ym. 2008).

Lehmien insuliiniresistenssillä ja ihmisen tyypin 2 diabeteksen puhkeamisella on ilmeisesti osittain samantyyppinen kehityskulku. Aiemmissa tutkimuksissa on osoitettu, että runsaasti tyydyttyneitä rasvahappoja sisältävän talin infuusio heikensi ummessaolevien, ei-tiineiden lypsylehmien plasman glukoosin poistumista ja lisäsi insuliiniresistenssiä glukoosirasituskokeen perusteella arvioituna (Pires ym. 2007). Toisaalta tiedetään, että tyydyttymättömiä rasvahappoja sisältävät rasvat voivat ehkäistä insuliiniresistenssin kehittymistä ihmisillä (Lee ym. 2005, Corcoran ym. 2007). Myös ummessaolevien, ei-tiineiden lypsylehmien insuliinivaste parani runsaasti monityydyttymättömiä rasvahappoja (C18:3 n-3 osuus 50-60\% rasvahapoista) sisältävän pellavansiemenöljyinfuusion vaikutuksesta (Pires ym. 2008).

Tämän tutkimuksen tarkoituksena oli selvittää juoksutusmahaan infusoidun rasvalisän aiheuttaman veren NEFA-pitoisuuden lisääntymisen vaikutusta tiineiden, ummessaolevien lypsylehmien insuliiniresistenssin kehittymiseen. Vaikutusta tutkittiin glukoosirasitus- ja insuliinivastekokeiden avulla. Lisäksi haluttiin selvittää, onko annetun rasvan (tali vs. camelinaöljy) rasvahappokoostumuksella vaikutusta lehmän glukoosinsietoon ja insuliinivasteeseen rasitus- ja vastekokeiden aikana. Camelinaöljy sisältää runsaasti monityydyttymätöntä alfalinoleenihappoa, jonka osuus on 35-40 \% rasvahappokoostumuksesta. Tali koostuu pääosin tyydyttyneistä palmitiini- ja steariinihaposta sekä kertatyydyttymättömästä öljyhaposta (C18:1), joiden osuus on yhteensä n. $85 \%$ talin rasvahappokoostumuksesta (Pires ym. 2008). Rasvahappoinfuusion vaikutusta lehmien insuliiniresistenssiin ei ole tutkittu tiineillä, ummessaolevilla lehmillä.

\section{Aineisto ja menetelmät}

Tutkimus tehtiin Viikin opetus- ja tutkimustilan navetassa 15.9.-14.10.2008. Koe-eläiminä oli kuusi toista kertaa poikivaa, ummessaolevaa, pötsifistelöityä ay-lehmää. Koemalli oli 3 x 3 latinalainen neliö, joka toistettiin kahtena erillisenä neliönä. Koejaksojen kesto oli viisi vuorokautta, ja jaksojen välissä oli samanpituinen tauko. Kokeen ensimmäisen jakson alkaessa lehmien todelliseen poikimispäivään oli aikaa keskimäärin 43 pv, ja kokeen viimeisen jakson loputtua keskimäärin 18 pv (keskihajonta 3,7 pv). Koekäsittelyt olivat juoksutusmahaan infusoitu vesi (V), tali (T) ja camelinaöljy (C). Infusoitu rasva/vesimäärä oli $500 \mathrm{ml} / \mathrm{pv}$, joka annettiin $10 \mathrm{kerta}-$ annoksena $(50 \mathrm{ml} / \mathrm{krt})$ kahden tunnin välein klo 6.00-24.00. Talia sulatettiin infuusiota varten päivittäin tarvittava annos. Infuusiot annettiin $100 \mathrm{ml}$ injektioruiskulla pötsifistelin korkin läpi kulkevan letkun kautta juoksutusmahaan. Infuusioletkun auki pysymisen varmistamiseksi lehmille annettiin lisäksi kullakin infuusiokerralla $150 \mathrm{ml}$ lämmintä vettä n. $\left(37^{\circ} \mathrm{C}\right)$ ja $10 \mathrm{ml}$ 80-\% etanolia. Infuusioletkun paikallaan pysyminen juoksutusmahassa tarkastettiin vähintään kahdesti päivässä.

Koejaksojen aikana lehmille annettiin seosrehua $90 \%$ laskennallisesta energian tarpeesta; todellinen energiansaanti oli rehuanalyysien jälkeen laskettuna keskimäärin $95 \%$ tarpeesta. Rasvainfuusioiden sisältämä energiamäärä huomioitiin energian saantia laskettaessa. Koejaksojen välissä lehmät saivat samaa seosrehua laskennallisen energian tarpeen mukaisesti. Seosrehun raaka-aineina olivat esikuivattu nurmisäilörehu ja heinä (80:20 \% kuiva-aineesta). Kivennäinen annettiin erikseen. Eläimet 
punnittiin ennen kunkin jakson alkua kahtena peräkkäisenä päivänä. Kuntoluokitus tehtiin kokeen alussa ja lopussa.

Glukoosirasitus- ja insuliinivastekokeita varten lehmille asetettiin katetrit molempiin kaulalaskimoihin jakson neljäntenä päivänä iltapäivällä. Glukoosirasituskoe tehtiin jakson viidennen päivän aamuna klo 9.00 infusoimalla kaulalaskimoon asetetun katetrin kautta suoneen 0,25 g/elopainokilo glukoosia (Glucos. B. Braun $300 \mathrm{mg} / \mathrm{ml}$ ) ja ottamalla verinäytteitä katetrin kautta $-15,-5,5,10,15,20$, 30, 40, 50, 60, 90, 120, 150 ja 180 min kuluttua infuusiosta. Samana päivänä klo 19.00 tehtiin insuliinivastekoe infusoimalla katetrin kautta suoneen 0,1 IU/elopainokilo insuliinia (Humulin Regular 100 IU/ml, Lilly Pharma) ja ottamalla verinäytteitä katetrin kautta -15, -5, 5, 10, 15, 20, 30, 40, 50, 60, 90 ja 120 min kuluttua infuusiosta. Lehmät olivat paastolla $1 \mathrm{~h}$ ennen kokeita sekä niiden aikana. Rasvainfuusioita ei annettu kokeiden aikana. Lisäksi lehmiltä otettiin verinäytteet kaulalaskimokatetrien asettamisen yhteydessä koejakson 4. päivänä maitosuonesta ennen iltaruokintaa ja 5. päivänä ennen aamuruokintaa kaulalaskimokatetrin kautta. Verinäytteistä määritettiin plasman glukoosi- ja NEFApitoisuudet spektrofotometrisesti, insuliinipitoisuus määritettiin RIA-menetelmällä.

Rasitus- ja vastekokeiden NEFA-, glukoosi- ja insuliinipitoisuuksista laskettiin SASohjelmistoon (versio 9.1) luodun makron avulla puolisuunnikasmenetelmää käyttäen lähtötason ylätai alapuolelle jäävän pitoisuus-aikakäyrän alainen pinta-ala (AUC, mmol/l x 60/120/180 min). Pitoisuuksien lähtöarvoina käytettiin 15 ja 5 min ennen kokeita otettujen verinäytteiden pitoisuuksien keskiarvoa. Kokeiden aikaisten glukoosi- ja insuliinipitoisuuksien poistumisnopeuden (CR, \%/min) ja puoliintumisajan $\left(\mathrm{T}_{1 / 2}, \mathrm{~min}\right)$ laskemiseksi pitoisuuksiin sovitettiin ensin epälineaarinen malli SAS:n NLIN-proseduurilla. Mallin tulosten perusteella laskettiin poistumisnopeus kaavalla: $\mathrm{CR}=100 *$ $(\ln [\mathrm{ta}]-\ln [\mathrm{tb}]) /(\mathrm{tb}-\mathrm{ta})$, missä [ta] ja [tb] ovat pitoisuudet ajan hetkellä a ja b. Puoliintumisaika laskettiin kaavalla: $\mathrm{T}_{1 / 2}=(\ln [2] / \mathrm{CR}) * 100$.

Tilastollinen testaus tehtiin toistettujen mittausten mallilla käyttäen SAS-ohjelmiston (versio 9.1) Mixed-proseduuria. Kiinteinä tekijöinä mallissa olivat käsittelyn, jakson ja neliön vaikutus jakson sisällä. Lehmän vaikutus neliön sisällä oli mallissa mukana satunnaisena tekijänä. Rasvalisän vaikutuksen testaukseen käytettiin ortogonaalisia kontrasteja: kontrolli vs. rasvalisät (vesi vs. tali + camelinaöljy) sekä tali vs. camelinaöljy.

\section{Tulokset ja tulosten tarkastelu}

Muuntokelpoisen energian (ME) saannissa ei ollut käsittelyjen välisiä eroja ( $\mathrm{p}=0,07)$, kun rasvalisän sisältämä energia huomioitiin päivittäisen rehuannoksen määrää laskettaessa. ME-saanti oli keskimäärin 94,2 MJ/pv (V), 93,6 MJ/pv (T) ja 93,3 MJ/pv (C). ME-saanti oli keskimäärin $95 \%$ kahdeksannella tiineyskuukaudella olevan lypsylehmän ruokintanormien (MTT 2006) mukaisesta energiantarpeesta. Vesikäsittelyn aikana energiatase oli keskimäärin $-4,5 \mathrm{MJ} \mathrm{ME} / \mathrm{pv}$, mikä poikkesi merkitsevästi $(\mathrm{p}=0,02)$ tali- $(-5,0 \mathrm{MJ} \mathrm{ME} / \mathrm{pv})$ ja camelinaöljykäsittelyn (-5,5 MJ ME/pv) aikaisesta energiataseesta. Energiataseessa havaitut erot johtuivat todennäköisesti seosrehun sisältämän säilörehun ennakkoon arvioitua paremmasta $\mathrm{D}$-arvosta. Seosrehun kuiva-aineen syönti oli vesikäsittelyllä keskimäärin 8,6 $\mathrm{kg} / \mathrm{pv}$ ja rasvakäsittelyillä $7,3 \mathrm{~kg}(\mathrm{P}<0,0001)$.

Tali- ja camelinaöljyinfuusiot suurensivat koejaksojen aikana odotetusti lehmien plasman NEFA-pitoisuutta $(\mathrm{P}<0,01)$ vesikäsittelyyn verrattuna. Piresin ym. (2007) tutkimuksessa tali-infuusion vaikutus oli samanlainen ei-tiineiden, ummessaolevien lehmien NEFA-pitoisuuteen. Jaksojen viimeisen päivän aamuna, ennen ruokintaa otettujen verinäytteiden plasman NEFA-pitoisuudet olivat keskimäärin $0,17 \mathrm{mmol} / \mathrm{l}(\mathrm{V}), 0,28 \mathrm{mmol} / \mathrm{l}(\mathrm{T}) \mathrm{ja} 0,25 \mathrm{mmol} / \mathrm{l}(\mathrm{C})$. Rasvakäsittelyjen välillä ei ollut eroa plasman NEFA-pitoisuuksissa, yhtäpitävästi aiempien tutkimusten kanssa (Pires ym. 2008, Brickner ym. 2009). Myöskään glukoosi- ja insuliinipitoisuuksissa ei ollut käsittelyjen välisiä eroja ennen rasitus- ja vastekokeita.

\section{Glukoosirasituskoe}

Insuliiniresistenssiä voidaan arvioida mittaamalla endogeenisen insuliinin vaikutusta glukoosinsietoon glukoosirasituskokeen aikana (Hayirli ym. 2002). Rasituskokeessa arvioidaan plasman insuliini- ja glukoosivastetta glukoosikuormituksessa näiden huippupitoisuuksien, pitoisuus-aikakäyrän alaisen pinta-alan (AUC) sekä puoliintumisajan $\left(\mathrm{T}_{1 / 2}\right)$ ja poistumisnopeuden (CR) avulla. Heikentynyt glukoosinsieto havaitaan glukoosirasituskokeen aikana glukoosin AUC-arvon suurenemisena, poistumisnopeuden pienentymisenä ja/tai puoliintumisajan suurenemisena (Muniyappa ym. 2008). 
Glukoosirasituskokeen aikana plasman NEFA-pitoisuus oli rasvakäsittelyjen vaikutuksesta korkeampi kuin vesikäsittelyllä $(\mathrm{P}<0,01)$ (Taulukko 1). Tali- ja camelinöljyinfuusion välillä ei ollut eroja plasman NEFA-pitoisuuksissa. Plasman NEFA-pitoisuus pienenee tyypillisesti glukoosirasituskokeen aikana (Hayirli ym. 2002) insuliinin vaikutuksesta, sillä insuliini vähentää rasvojen hajoamista pienentämällä cAMP:n pitoisuutta ja inhiboimalla proteiinikinaasiA:n ja hormonisensitiivisen lipaasin (HSL) aktiivisuutta (Brockman 1979). NEFA-pitoisuuden muutoksessa ei ollut käsittelyjen välisiä eroja glukoosirasituskokeen aikana, sillä NEFA:n puoliintumisajassa, poistumisnopeudessa tai AUCarvossa ei ollut tilastollisesti merkitsevää eroa.

Glukoosirasituskokeen perusteella arvioituna rasvakäsittelyt heikensivät endogeenisen insuliinin stimuloimaa glukoosin soluunottoa. Tämä havaittiin rasvakäsittelyjen osalta glukoosin poistumisnopeuden hidastumisena $(\mathrm{P}=0,023)$ ja puoliintumisajan suurenemisena $(\mathrm{P}=0,014)$ (Taulukko 1$)$. Tali- ja camelinaöljykäsittelyjen välillä ei ollut eroa glukoosin poistumisessa, yhtäpitävästi aiemman tutkimuksen kanssa (Pires ym. 2008).

Päinvastoin kuin Piresin ym. (2007) tutkimuksessa, nyt tehdyssä glukoosirasituskokeessa endogeeninen insuliinin eritys ei muuttunut koekäsittelyjen vaikutuksesta. Insuliinin huippuarvossa ei ollut käsittelyjen välisiä eroja, ei myöskään insuliinin poistumista kuvaavissa parametreissä (CR, T1/2 ja AUC) (Taulukko 1).

\section{Insuliinivastekoe}

Insuliinivastekokeen perusteella voidaan arvioida ääreiskudosten insuliiniherkkyyttä. Plasman insuliinipitoisuus suurenee vastekokeen aikana yli fysiologisen pitoisuuden ja vähenee nopeasti perustasolle. Glukoosin poistumisen perusteella voidaan arvioida maksimaalista insuliinivastetta tai insuliiniresistenssin voimakkuutta (Pires 2008). Glukoosin lähtöpitoisuudessa ei ollut käsittelyjen välisiä eroja insuliinivastekokeen aikana. Glukoosin minimipitoisuus oli vesikäsittelyllä pienempi $(\mathrm{P}=0,04)$ kuin rasvakäsittelyillä. Rasvakäsittelyt hidastivat glukoosin poistumista plasmasta insuliinivastekokeen aikana, sillä glukoosin poistumisnopeus $\left(\mathrm{CR}_{60} \% / \mathrm{min}\right)$ oli ensimmäisen tunnin aikana pienempi tali- ja camelinaöljykäsittelyillä $(\mathrm{P}=0,01)$ vesi-infuusioon verrattuna. Lisäksi rasvakäsittelyt pidensivät glukoosin puoliintumisaikaa $\left(\mathrm{T} 1 / 2_{60}(\min )\right)$ vesikäsittelyyn verrattuna $(\mathrm{P}=0,026)$, ja pitoisuus-aikakäyrän alainen pinta-ala $\left(\mathrm{AUC}_{120}\right)$ oli itseisarvoltaan pienempi (Taulukko 2).

Insuliinivastekokeen aikana ei havaittu koekäsittelyjen välisiä eroja insuliinin poistumisnopeudessa, puoliintumisajassa eikä AUC-arvoissa. Rasvakäsittelyjen vaikutuksesta insuliinin lähtöpitoisuus oli suuntaa-antavasti pienempi $(\mathrm{P}=0,09)$ kuin vesikäsittelyllä. Camelinaöljykäsittelyllä insuliinin huippupitoisuus oli suuntaa-antavasti pienempi kuin tali- ja vesikäsittelyillä $(\mathrm{P}=0,07)$ (Taulukko 2). Koska insuliinin poistumista kuvaavissa parametreissä ei havaittu käsittelyjen välisiä vaikutuksia, voidaan olettaa, että rasvakäsittelyt ovat vaikuttaneet insuliinin eritykseen, eivät sen poistumiseen elimistöstä.

Rasvahappojen tiedetään heikentävän haiman $\beta$-solujen toimintaa ja insuliinin tuotantoa ihmisillä (Zhou ja Grill 1995) ja rotilla (Maedler ym. 2001). Bossaertin ym. (2008) mukaan lypsylehmien glukoosin stimuloima insuliinin eritys heikkenee suuren NEFA-pitoisuuden vaikutuksesta. Mashekin ym. (2005) tutkimuksessa pellavansiemenöljyinfuusio pienensi plasman insuliinipitoisuutta taliinfuusioon verrattuna. Heidän mukaansa pellavansiemenöljy vaikutti insuliinin eritykseen. Lisäksi tiedetään, että erilaisten rasvojen rasvahappokoostumus vaikuttaa eri tavoin insuliinin eritykseen (Xiao ym. 2006).

Toisaalta vesikäsittelyjen aikana eläimet söivät $\mathrm{n} .1,3 \mathrm{~kg}$ enemmän seosrehun kuivaainetta/pv kuin rasvakäsittelyiden aikana. Tällöin eläimet ovat mahdollisesti saaneet rehusta enemmän glukogeenisiä esiaineita (lähinnä propionihappoa), mikä saattaa lisätä veren insuliinipitoisuutta. Glukoosin lähtöpitoisuuksissa ei ollut käsittelyjen välisiä eroja, sillä elimistön fysiologinen säätely pyrkii pitämään plasman glukoosipitoisuuden vakiona (Bell 1995). 
Taulukko 1. Juoksutusmahaan infusoidun veden, talin tai camelinaöljyn vaikutukset plasman NEFA-, glukoosi- ja insuliinipitoisuuksiin glukoosirasituskokeen aikana.

\begin{tabular}{|c|c|c|c|c|c|c|}
\hline & \multicolumn{3}{|c|}{ Käsittely } & \multirow[b]{2}{*}{ SEM } & \multicolumn{2}{|c|}{ P-arvo } \\
\hline & Kontrolli & Tali & Camelina & & $\begin{array}{l}\text { Kontrolli } \\
\text { vs. Rasva }\end{array}$ & $\begin{array}{l}\text { Tali vs. } \\
\text { Camelina }\end{array}$ \\
\hline \multicolumn{7}{|l|}{ NEFA } \\
\hline Lähtöarvo (mmol/l) & 0,11 & 0,21 & 0,23 & 0,026 & $* *$ & \\
\hline Minimiarvo (mmol/l) & 0,04 & 0,10 & 0,11 & 0,010 & $* * *$ & \\
\hline \multicolumn{7}{|l|}{ Glukoosi } \\
\hline Huippuarvo (mmol/l) & 18,63 & 17,55 & 17,42 & 0,44 & $*$ & \\
\hline $\mathrm{CR}_{120}(\% / \mathrm{min})$ & 1,40 & 1,15 & 1,04 & 0,12 & $*$ & \\
\hline $\mathrm{T} 1 / 2_{120}(\mathrm{~min})$ & 52,3 & 61,1 & 69,3 & 5,1 & $*$ & \\
\hline $\mathrm{AUC}_{120}(\mathrm{mmol} / \mathrm{l} \times 120 \mathrm{~min})$ & 562 & 557 & 598 & 31,1 & & \\
\hline \multicolumn{7}{|l|}{ Insuliini } \\
\hline Huippuarvo ( $\mu \mathrm{IU} / \mathrm{ml})$ & 128 & 113 & 104 & 14,1 & & \\
\hline $\mathrm{CR}_{180}(\% / \mathrm{min})$ & 0,79 & 0,74 & 0,65 & 0,092 & & \\
\hline $\mathrm{AUC}_{180}(\mu \mathrm{IU} / \mathrm{ml} \times 180 \mathrm{~min})$ & 6704 & 7170 & 5886 & 768 & & \\
\hline
\end{tabular}

Taulukko 2. Juoksutusmahaan infusoidun veden, talin tai camelinaöljyn vaikutukset plasman NEFA-, glukoosi- ja insuliinipitoisuuksiin insuliinivastekokeen aikana.

\begin{tabular}{|c|c|c|c|c|c|c|}
\hline & \multicolumn{3}{|c|}{ Käsittely } & \multirow[b]{2}{*}{ SEM } & \multicolumn{2}{|c|}{ P-arvo } \\
\hline & Kontrolli & Tali & Camelina & & $\begin{array}{l}\text { Kontrolli } \\
\text { vs. Rasva }\end{array}$ & $\begin{array}{l}\text { Tali vs. } \\
\text { Camelina }\end{array}$ \\
\hline \multicolumn{7}{|l|}{ NEFA } \\
\hline Lähtöarvo (mmol/l) & 0,07 & 0,19 & 0,21 & 0,02 & $* * *$ & \\
\hline Minimiarvo (mmol/l) & 0,04 & 0,11 & 0,12 & 0,02 & $* * *$ & \\
\hline \multicolumn{7}{|l|}{ Glukoosi } \\
\hline Minimiarvo (mmol/l) & 2,05 & 2,30 & 2,22 & 0,099 & $*$ & \\
\hline $\mathrm{CR}_{60}(\% / \mathrm{min})$ & 1,02 & 0,66 & 0,83 & 0,074 & $*$ & \\
\hline $\mathrm{T} 1 / 2_{60}(\min )$ & 69,9 & 108,4 & 88,9 & 9,18 & $*$ & \\
\hline $\mathrm{AUC}_{60}(\mathrm{mmol} / 1$ x $60 \mathrm{~min})$ & $-83,2$ & $-68,7$ & $-66,3$ & 4,6 & $* *$ & \\
\hline \multicolumn{7}{|l|}{ Insuliini } \\
\hline Lähtöarvo ( $\mu \mathrm{IU} / \mathrm{ml})$ & 27,3 & 23,3 & 18,7 & 3,17 & $\circ$ & \\
\hline Huippuarvo( $\mu \mathrm{IU} / \mathrm{ml})$ & 1517 & 1643 & 1168 & 14,1 & & $\circ$ \\
\hline $\mathrm{AUC}_{60}(\mu \mathrm{IU} / \mathrm{ml}$ x $60 \mathrm{~min})$ & 17253 & 18022 & 16548 & 1037 & & \\
\hline
\end{tabular}

\section{Johtopäätökset}

Koetulosten perusteella voidaan todeta, että rasvainfuusioiden avulla aiheutettu veren hyperlipidemia heikensi lypsylehmien endogeenisen insuliinin stimuloimaa glukoosin soluunottoa poikimisen läheisyydessä glukoosirasitus- ja insuliinivastekokeiden aikana. Koska tali- ja camelinaöljykäsittelyjen välillä ei ollut eroja glukoosin poistumisessa, tulokset eivät tue teoriaa, jonka mukaan runsaasti tyydyttymättömiä rasvahappoja sisältävä rasvalisä parantaa insuliiniherkkyyttä.

\section{Kirjallisuus}

Bell, A.W. 1995. Regulation of organic nutrient metabolism during transition from late pregnancy to early lactation. Journal of Animal Science 73:2804-2819.

Bossaert, P., Leroy, J.L.M.R., Vliegher, S. d. \& Opsomer, G. 2008. Interrelations between glucose-induced insulin response, metabolic indicators, and time of first ovulation in high-yielding dairy cows. Journal of Dairy Science 91: 3363-3371.

Brickner, A.E., Pires, A.A., Gressley, T.F. \& Grummer, R.R. 2009. Effects of abomasal lipid infusion on liver triglyceride accumulation and adipose lipolysis during fatty liver induction in dairy cows. Journal of Dairy Science 92: 4954-4961. 
Brockman, R.P. 1979. Roles for insulin and glucagon in the development of ruminant ketosis. The Canadian veterinary journal 20: 121-126.

Corcoran, M.P., Lamon-Fava, S. \& Fielding, R. 2007. Skeletal muscle lipid deposition and insulin resistance: effect of dietary fatty acids and exercise. American Journal of Clinical Nutrition 85:662-677.

Haffner S.M., Miettinen H., Gaskill S.P. \& Stern M.P. 1995. Decreased insulin secretion and increased insulin resistance are independently related to the 7-year risk of NIDDM in Mexican-Americans. Diabetes 44: 13861391.

Hayirli, A., Bertics, S.J. \& Grummer, R.R. 2002. Effects of slow-release insulin on production, liver triglyceride, and metabolic profiles of Holsteins in early lactation. Journal of Dairy Science 85: 2180-2191.

Lee, J.S., Pinnamaneni, S.K., Eo, S.J., Cho, I.H., Pyo, J.H., Kim, C.K., Sinclair, A.J., Febbraio, M.A. \& Watt, M.J. 2005. Saturated, but not $n-6$ polyunsaturated, fatty acids induce insulin resistance: role of intramuscular accumulation of lipid metabolites. Journal of Applied Physiology 100: 1467-1474.

Lewis, G.F., Carpentier, A., Adeli, K. \& Giacca, A. 2002. Disordered fat storage and mobilization in the pathogenesis of insulin resistance and type 2 diabetes. Endocrine reviews 23: 201-229.

Maedler, K., Spinas, G.A., Dyntar, D., Moritz, W., Kaiser, N. \& Donath, M.Y. 2001. Distinct effects of saturated and monounsaturated fatty acids on $\beta$-cell turnover and function. Diabetes 50: 69-76.

Mashek, D.G., Bertics, S.J. \& Grummer, R.R. 2005. Effects of intravenous triacylglycerol emulsions on hepatic metabolism and blood metabolites in fasted dairy cows. J. Dairy Sci. 88:100-109.

Muniyappa, R., Lee, S., Chen, H. \& Quon, M.J. 2008. Current approaches for assessing insulin sensitivity and resistance in vivo: advantages, limitations, and appropriate usage. American journal of physiology: endocrinology and metabolism 294: 15-26.

MTT 2006. Rehutaulukot ja ruokintasuositukset. URL = http://www.agronet.fi/rehutaulukot/ Viitattu 15.11.2009.

Oikawa, S. \& Oetzel, G.R. 2006. Decreased insulin response in dairy cows following a four-day fast to induce hepatic lipidosis. Journal of Dairy Science 89: 2999-3005.

Pires, J.A.A., Souza, A.H. \& Grummer, R.R. 2007. Induction of hyperlipidemia by intravenous infusion of tallow emulsion causes insulin resistance in Holstein cows. Journal of Dairy Science 90: 2735-2744.

Pires, J.A.A, Pescara, J., Brickner, A., Rio, N., Cunha, A.P. \& Grummer, R.R. 2008. Effects of abomasal infusion of linseed oil on responses to glucose and insulin in Holstein cows. Journal of Dairy Science 91: 13781390.

Xiao, C., Giacca, A., Carpentier, A. \& Lewis, G. F. 2006. Differential effects of monounsaturated, polyunsaturated and saturated fat ingestion on glucose-stimulated insulin secretion, sensitivity and clearance in overweight and obese, non-diabetic humans. Diabetologia 49: 1371-1379.

Zhou, Y. P. \& Grill, V. 1995. Long term exposure to fatty acids and ketones inhibits B-cell functions in human pancreatic islets of Langerhans. The Journal of clinical endocrinology and metabolism 80: 1584-1590. 